\title{
Climate-related reporting by publicly listed companies in The Netherlands: an attention-action mapping
}

\author{
Jan Stolker, Bahar Keskin den Doelder, Jatinder S. Sidhu
}

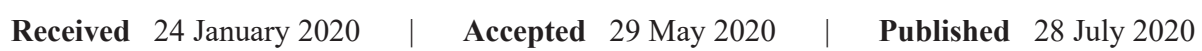

\begin{abstract}
Against the backdrop of increasing calls for mandatory and voluntary climate-related disclosures by companies, this article provides insight into how the (integrated) annual reports of companies listed on the AEX index in the Netherlands, communicated companies' engagement with climate issues from 2016 to 2018. Drawing on research in the cognitive psychology domain, the article examines companies' reported attention to climate change as well as their climate-related actions. It shows that although there are noticeable climate attention and action differences among AEX companies, over time the companies as a whole have started doing more in relation to climate - for example, in terms of attention, there is increase in the inclusion of climate considerations in strategy making and, in terms of action, there is increase in the inclusion of climate in material risks. The article discusses the research findings, which have implications for effective governance by corporate boards.
\end{abstract}

\section{Relevance to practice}

This article shows that the engagement of AEX companies with climate issues has increased since 2016. Still, there remains more to be done in terms of attention to climate change and the taking of climate-related actions, as well as reporting to shareholders and stakeholders. While the article is based on the (integrated) annual reports of AEX companies, its common message for all firms is that the need for addressing the potential risks and opportunities arising from climate change and for clearly communicating a company's climate actions is too important and urgent to be left unattended. The article underscores the important role that non-executive directors on (supervisory) boards can play in this regard.

\section{Keywords}

Climate reporting, attention to climate, climate actions, AEX companies, SDG 13, non-executive directors

\section{Introduction}

As a new decennium starts, academic and public consensus continues to shift towards the view that the pursuit of profits and social goals by business corporations need not imply the pursuit of either opposing or mutually exclusive ends (Eccles et al. 2014; Porter and Kramer 2011). There is thus greater incentive for companies, as well as greater pressure on them from governments, investors, lenders, insurers and other stakeholders to invest more in setting and achieving social goals in addition to financial ones (Kamp-Roelands et al. 2019; Reid and Toffel 2009). In this context, the calls for voluntary as well as mandatory reporting of corporate engagement with environmental, social and governance (ESG) issues have grown in the last ten years. Such reporting is expected to facilitate not only informed investment decisions in corporate stocks and bonds by socially oriented investors, but also allow other categories of stakeholders to evaluate whether they wish to associate with a company based on its ESG performance (Bebbington et al. 2008; Plumlee et al. 2015).

At present, several financial-market organizations compile and disseminate companies' ESG-related ratings. Thus, interested parties can turn to, for instance, the Bloomberg 
ESG data, the Dow Jones Sustainability Index and the FTSE4Good Index. A concern with such ratings as well as self-disclosures by companies is that in the absence of clear regulations and universal standards, companies' ESG scores entail subjectivity and are not easily verifiable and comparable across firms and industries (e.g., Stubbs and Rogers 2013). With regard to environment-related scores in particular, to enable availability of consistent, comparable data, several frameworks and guidelines have been proposed by, among others, CDP (formerly, Carbon Disclosure Project), the Climate Disclosure Standards Board (CDSB), the Sustainability Accounting Standards Board (SASB) and the Task Force on Climate-related Financial Disclosures (TCFD). The CDSB and TCFD guidelines seek to encourage lucid self-disclosures in mainstream corporate reports, such that, a company's impact on climate, the climate-related risks and opportunities the company faces, and the company's efforts to promote sustainability are communicated transparently to stakeholders.

With the above as background, this article examines how the corporate reports of publicly listed companies on the AEX index in the Netherlands communicated or reported their engagement with climate issues in the threeyear period from 2016 to 2018. Because the AEX index includes companies whose shares are most frequently traded on the stock exchange, the companies on the index have strong incentive and face strong stakeholder pressure to address climate concerns (e.g., Flammer 2013). Furthermore, the 2016-2018 period is an interesting one to study because of the greater sense of urgency created to tackle climate concerns by several developments, such as, the 2015 Paris Agreement signed by the governments of 195 countries to limit global warming to under $2{ }^{\circ} \mathrm{C}$. More recently, in 2017, the EU's Non-Financial Reporting Directive (NFRD) came into effect in the Netherlands, making inclusion of non-financial information in annual reports compulsory, covering periods starting on or after 1 January 2017. Furthermore, in 2019, the EU announced its non-binding guidelines on reporting climate-related information. Regulators in several EU countries have shown support for the guidelines and indicated that they will enforce compliance with them. These developments have increased pressure on companies to publicly disclose both the impact of their business activities on climate and the climate-related policies they have put in place.

Our analysis reveals variation across companies in terms of the attention they paid to climate and the concrete actions they took to deal with climate-related issues. Furthermore, our analysis also shows an attention-action correspondence - companies that paid less attention to the climate factor were also the ones that took less actions to tackle climate concerns. In addition, the analysis indicates some change over time in individual companies' engagement with climate-related issues. We start below, in Section 2, by outlining the research background. Section 3 describes the research methodology in terms of the corporate reports that were examined, and the indicators that were used to measure companies' attention to climate and companies' climate-related actions. Section 4 reports and discusses the study's findings. Section 5 presents a concluding discussion centering on the implications of the study's findings for practitioners and researchers; the section also offers suggestions for future research.

\section{Research background}

Contrary to Friedman's (1970) classic thesis that society is best served when the focus of business corporations is on increasing shareholder value and not on social responsibilities, academic research increasingly indicates that companies may, in fact, be able to improve their financial performance and create more shareholder value while pursuing social-responsibility goals (Ioannou and Serafeim 2015; Ortiz-de-Mandojana and Bansal 2016). Indeed, in the current socio-political context, profit-focused companies that disregard environmental, social and governance (ESG) issues run the risk of eroding their competitive position by losing social legitimacy and alienating stakeholders (Beck et al. 2017; Flammer 2013). Although companies apparently can expect to benefit from pursuing social goals, there is much variation in the emphasis on realization of such goals across firms in different industries, sectors and nations. (BCG Report 2017; KPMG et al. 2018).

In relation to climate-related social goals, for example, companies differ with respect to voluntarily reporting their engagement with climate-related concerns, suggesting differences in whether climate goals are pursued. The incentive and pressure on companies to communicate their focus on climate issues to stakeholders has, however, increased vastly in the last decade as public concern about global warming and sustainability has grown. In this regard, the 2015 Paris Agreement, the inclusion of "climate action" as one of the U.N.'s SDGs, the 2014 EU's Non-Financial Reporting Directive that came into effect in the Netherlands in 2017, information demands from investors and other stakeholders, and efforts by governmental and private institutes and organizations to provide recommendations and tools that facilitate climate-related disclosures are important developments that are pressing companies harder to engage with climate issues.

The attention-action framework constitutes a useful template for documenting companies' engagement with climate issues. Attention is an important psychological construct, which captures the cognitive processes of noticing and interpreting specific environmental cues and devoting time and effort to acquiring information related to them (Kahneman 1973; Ocasio 1997). Whether and to what extent a company's attention is directed to cues concerning the impact its business has on climate, the risks and opportunities posed by climate change, and formulation of climate goals is dependent on the company's corporate leadership. A company's CEO, top management team (TMT) of senior-most executives, and non-executive board directors (NEDs) can be expected to have most influence on company's attention focus by virtue of being the decision-making 
group with most responsibility and power for charting the company's strategic course (Hambrick and Mason 1984; Kor 2006; Westphal and Fredrickson 2001). It is however the case that because NEDs are not directly involved in the day-to-day operations of a company, their influence might be constrained by information asymmetry. For instance, although NEDs have a fiduciary duty to ensure that a firm addresses material risks and opportunities associated with climate change, they may not have enough pertinent information to offer proper counsel and guidance.

The attention focus of corporate leaders is postulated to be the precursor of action (Li et al. 2013; Shepherd et al. 2017). Research shows, for example, that CEO attention to an emerging technology is associated with faster entry into a new market (Eggers and Kaplan 2009) and that TMT's attention change is a precondition for change in strategy (Cho and Hambrick 2006). However, the level of attention to an issue may not always be commensurate with actions taken to address that issue. For instance, a company may not have the requisite resources to take actions to mitigate risks and exploit opportunities related to climate (cf. Nadkarni and Chen 2014). In addition, the attention evident to climate in a company's vision and other rhetoric may not find expression in actual climate-related actions due to decoupling of legitimacy-enhancing corporate intent from actual practices (Weaver et al. 1999). Thus, while attention to climate in corporate reports may indicate awareness or recognition of climate as a pressing social issue by corporate leaders, action represents a more concrete expression of organizational commitment to addressing climate concerns. In research on communication of corporate social responsibility, the gap between attention and action is captured by the idiom "not walking the talk" (Crane and Glozer 2016).

This study employs the attention-action framework to examine how publicly listed companies in the Netherlands communicate their engagement with climate issues in corporate reports. In particular, we map the attention paid to climate issues as well as the climate-related actions taken by the companies. The mapping exercise seeks to establish whether there are differences among companies in their attention and actions, and how companies' attention and actions changed over the three-year period from 2016 to 2018. Such a descriptive account of companies' engagement with climate issues constitutes an important first step towards developing better scholarly understanding of how and why companies' respond differently to incentives and pressures for more corporate social responsibility. It can also provide important practical insights for companies, which enable the effective balancing of shareholder expectations regarding financial performance with stakeholder expectations regarding climate-related social performance.

\section{Research methodology}

For the attention-action mapping, we focused on the 25 companies that were on the AEX listing in November
2019. As one of these companies was not listed on the AEX in 2016 and 2017, for these two years our sample comprised 24 companies. We obtained our data primarily from the companies' annual reports for 2016, 2017 and 2018. In addition, whenever an annual report referred to the annual sustainability report or an integrated annual report was available, we also examined the latter reports to assess company's engagement with climate issues. We employed a set of eight items to gauge companies' attention to climate and another set of eight items to gauge their climate actions. In particular, we systematically and diligently inspected all annual, integrated and sustainability reports to determine companies' annual score vis-à-vis each item. Specifically, with regard to each item, we instructed two trained research assistants to independently go through all reports, and extract and record all relevant text having bearing on an item. The assistants focused on text that was explicitly about climate change and ignored text that was only indirectly linked to climate change through a reference to, say, sustainability, or the usage of other common terms such as "ecological", "environmental" and "green". The assistants also noted down the page numbers on which extracted textual material appeared in the reports. After this, one of the paper's co-authors cross-checked whether there was clear correspondence between the textual material extracted by the assistants and the focal items. Any instances of doubtful correspondence were resolved through a discussion with the assistants and by examining texts in their context, i.e., by reading the texts in the reports they were extracted from. After this, we used the extracted textual material to assign scores to companies for each item for each year. Table 1 shows the sixteen items, the scoring scheme per item, and the number of companies that had a specific score per year. We summed up companies' individual scores on the attention and action items to arrive respectively at their annual attention to climate and climate action scores, which could range from 0 to 12 . These scores and the changes therein from 2016 to 2018 are shown in Table 2.

\section{Analysis and findings}

Looking at Table 1 first, one notes a general increase over time in the number of companies receiving higher scores on both the attention to climate and climate action items. Thus, from 2016 to 2018, the number of companies scoring " 0 " decreased, while the number of companies scoring either " 1 " or " 2 " increased. In relation to some items, though, there was a sharper increase in the percentage of companies that scored higher. For example, whereas in 2016 only 12 companies $(50 \%$ of the sample) had made a reference to "climate" in their strategy, by 2018 the number had increased to 21 companies $(88 \%$ of the sample). As another example, there was a sharp increase in the number of companies that had either quantified or qualified risks and opportunities connected to climate change - from 13 companies (54\% of the sample) in 2016 to 19 companies ( $76 \%$ of the sample) in 2018. These examples illustrate that more companies 
Table 1. Climate attention and action items, scoring schemes, and number of scoring companies per year.

\begin{tabular}{|c|c|c|c|c|}
\hline \multirow{2}{*}{ Atems } & \multirow[t]{2}{*}{ Scoring scheme } & \multicolumn{3}{|c|}{$\begin{array}{l}\text { Number of } \\
\text { companies }\end{array}$} \\
\hline & & 2016 & 2017 & 2018 \\
\hline \multirow{3}{*}{$\begin{array}{l}\text { 1. There is reference to } \\
\text { 'climate' in company's } \\
\text { mission statement }\end{array}$} & $\mathrm{Yes}=2$ & 0 & 0 & 0 \\
\hline & $\begin{array}{c}\text { Reference to } \\
\text { sustainability, but not } \\
\text { to climate specifically } \\
=1\end{array}$ & 3 & 6 & 5 \\
\hline & $\mathrm{No}=0$ & 21 & 18 & 20 \\
\hline \multirow{2}{*}{$\begin{array}{l}\text { 2. There is reference to } \\
\text { 'climate' in CEO's letter } \\
\text { to shareholders }\end{array}$} & Yes $=1$ & 8 & 12 & 11 \\
\hline & $\mathrm{No}=0$ & 16 & 12 & 14 \\
\hline \multirow{3}{*}{$\begin{array}{l}\text { 3. SDG } 13 \text { is prioritised } \\
\text { relative to other SDGs }\end{array}$} & Yes $=2$ & 5 & 9 & 9 \\
\hline & A little $=1$ & 2 & 4 & 3 \\
\hline & $\mathrm{No}=0$ & 17 & 11 & 13 \\
\hline \multirow{3}{*}{$\begin{array}{l}\text { 4. There is reference } \\
\text { to 'climate' in the } \\
\text { company's strategy }\end{array}$} & Explicitly $=2$ & 12 & 15 & 21 \\
\hline & Implicitly=1 & 2 & 1 & 0 \\
\hline & $\mathrm{No}=0$ & 10 & 8 & 4 \\
\hline \multirow{2}{*}{$\begin{array}{l}\text { 5. There is reference to } \\
\text { 'climate' in the report of } \\
\text { the supervisory board }\end{array}$} & Yes $=1$ & 5 & 5 & 9 \\
\hline & $\mathrm{No}=0$ & 19 & 19 & 16 \\
\hline \multirow{2}{*}{$\begin{array}{l}\text { 6. Risk/opportunity is } \\
\text { quantified or qualified }\end{array}$} & Yes $=1$ & 13 & 16 & 19 \\
\hline & $\mathrm{No}=0$ & 11 & 8 & 6 \\
\hline \multirow{3}{*}{$\begin{array}{l}\text { 7. Urgency to take action } \\
\text { is evident }\end{array}$} & Explicitly $=2$ & 11 & 12 & 16 \\
\hline & Implicitly=1 & 3 & 1 & 1 \\
\hline & $\mathrm{No}=0$ & 10 & 11 & 8 \\
\hline \multirow{2}{*}{$\begin{array}{l}\text { 8. Costs of } \mathrm{CO}_{2} \text { emissions } \\
\text { is mentioned and } \\
\text { quantified }\end{array}$} & Yes $=1$ & 4 & 5 & 5 \\
\hline & $\mathrm{No}=0$ & 20 & 19 & 20 \\
\hline \multicolumn{5}{|l|}{ B. Climate action } \\
\hline \multirow{2}{*}{$\begin{array}{l}\text { 1. Climate and/or } \mathrm{CO}_{2} \\
\text { are used for bonus/award } \\
\text { schemes }\end{array}$} & Yes $=1$ & 2 & 6 & 6 \\
\hline & $\mathrm{No}=0$ & 22 & 18 & 19 \\
\hline \multirow{3}{*}{$\begin{array}{l}\text { 2. Steps to address } \\
\text { climate change initiated }\end{array}$} & Several steps taken $=2$ & 15 & 17 & 21 \\
\hline & A step taken $=1$ & 4 & 5 & 3 \\
\hline & No steps taken $=0$ & 5 & 2 & 1 \\
\hline \multirow{3}{*}{$\begin{array}{l}\text { 3. Climate targets exist } \\
\text { and are monitored }\end{array}$} & Quantitative $=2$ & 16 & 16 & 17 \\
\hline & Qualitative $=1$ & 4 & 6 & 7 \\
\hline & $\mathrm{No}=0$ & 4 & 2 & 1 \\
\hline \multirow{2}{*}{$\begin{array}{l}\text { 4. There are requirements } \\
\text { for suppliers regarding } \\
\text { climate/CO }\end{array}$} & Yes $=1$ & 5 & 8 & 9 \\
\hline & $\mathrm{No}=0$ & 19 & 16 & 16 \\
\hline \multirow{2}{*}{$\begin{array}{l}\text { 5. Low-carbon products/ } \\
\text { services are offered }\end{array}$} & Yes $=1$ & 14 & 12 & 14 \\
\hline & $\mathrm{No}=0$ & 10 & 12 & 11 \\
\hline \multirow{2}{*}{$\begin{array}{l}\text { 6. Company includes } \\
\text { climate change in } \\
\text { material risks }\end{array}$} & Yes $=1$ & 11 & 13 & 16 \\
\hline & $\mathrm{No}=0$ & 13 & 11 & 9 \\
\hline \multirow{3}{*}{$\begin{array}{l}\text { 7. Carbon emissions are } \\
\text { reported }\end{array}$} & Scope $1,2 \& 3=2$ & 11 & 11 & 15 \\
\hline & Scope $1 \& 2=1$ & 9 & 9 & 6 \\
\hline & Not reported $=0$ & 4 & 4 & 4 \\
\hline \multirow{3}{*}{$\begin{array}{l}\text { 8. TCFD } \\
\text { recommendations are } \\
\text { used for reporting }\end{array}$} & $\begin{array}{c}\text { There is a TCFD } \\
\text { report }=2\end{array}$ & 0 & 3 & 7 \\
\hline & $\begin{array}{l}\text { Intention to use } \\
\text { TCFD }=1\end{array}$ & 3 & 7 & 6 \\
\hline & $\begin{array}{l}\text { No engagement with } \\
\text { TCFD }=0\end{array}$ & 21 & 14 & 12 \\
\hline
\end{tabular}

seem to be giving thought to climate issues when developing their strategy and business model. Furthermore, there seems to be an increasing sense of urgency on the part of companies to act. Whereas in 2016 only 11 companies ( $45 \%$ of the sample) had explicitly mentioned this urgency, in 2018 the number had increased to 16 (64\% of the sample). In addition, while in 2016 only 11 companies ( $46 \%$ of the sample) had included climate change in
Table 2. Yearly climate attention and action scores and changes over time.

\begin{tabular}{|c|c|c|c|c|c|c|c|c|}
\hline \multirow[b]{2}{*}{$\begin{array}{l}\text { Company / } \\
\text { YEAR }\end{array}$} & \multicolumn{4}{|c|}{ Climate action scores } & \multicolumn{4}{|c|}{ Climate attention scores } \\
\hline & 2016 & 2017 & 2018 & $\begin{array}{c}\text { Change } \\
2016- \\
2018\end{array}$ & 2016 & 2017 & 2018 & $\begin{array}{c}\text { Change } \\
2016- \\
2018\end{array}$ \\
\hline Aalberts Ind. & 2 & 4 & 6 & 4 & 0 & 3 & 4 & 4 \\
\hline ABN AMRO & 3 & 7 & 8 & 5 & 0 & 7 & 8 & 8 \\
\hline Adyen & n.a. & n.a. & 0 & n.a. & n.a. & n.a. & 0 & n.a. \\
\hline Aegon & 5 & 7 & 7 & 2 & 1 & 2 & 7 & 6 \\
\hline Ahold Delhaize & 7 & 7 & 9 & 2 & 5 & 4 & 8 & 3 \\
\hline Akzo Nobel & 9 & 9 & 8 & -1 & 9 & 8 & 5 & -4 \\
\hline ArcelorMittal & 8 & 8 & 8 & 0 & 4 & 8 & 10 & 6 \\
\hline ASML & 4 & 4 & 7 & 3 & 1 & 3 & 5 & 4 \\
\hline ASR Nederland & 7 & 9 & 9 & 2 & 4 & 7 & 8 & 4 \\
\hline DSM & 10 & 10 & 11 & 1 & 11 & 11 & 10 & -1 \\
\hline Galapagos & 0 & 0 & 2 & 2 & 0 & 0 & 0 & 0 \\
\hline Heineken & 7 & 8 & 9 & 2 & 6 & 8 & 6 & 0 \\
\hline IMCD & 0 & 2 & 5 & 5 & 0 & 0 & 2 & 2 \\
\hline ING Group & 9 & 11 & 11 & 2 & 5 & 6 & 7 & 2 \\
\hline KPN & 8 & 8 & 9 & 1 & 8 & 3 & 7 & -1 \\
\hline NN Group & 7 & 8 & 9 & 2 & 3 & 4 & 6 & 3 \\
\hline Philips & 8 & 9 & 11 & 3 & 7 & 6 & 10 & 3 \\
\hline $\begin{array}{l}\text { Randstad } \\
\text { Holding }\end{array}$ & 5 & 5 & 5 & 0 & 0 & 1 & 2 & 2 \\
\hline RELX Group & 6 & 6 & 8 & 2 & 5 & 3 & 5 & 0 \\
\hline $\begin{array}{l}\text { Royal Dutch } \\
\text { Shell }\end{array}$ & 6 & 8 & 8 & 2 & 7 & 10 & 10 & 3 \\
\hline Takeawaycom & 0 & 1 & 3 & 3 & 0 & 0 & 0 & 0 \\
\hline $\begin{array}{l}\text { Unibail- } \\
\text { Rodamco }\end{array}$ & 9 & 9 & 10 & 1 & 5 & 4 & 5 & 0 \\
\hline Unilever & 8 & 9 & 11 & 3 & 8 & 11 & 10 & 2 \\
\hline Vopak & 3 & 6 & 8 & 5 & 5 & 7 & 6 & 1 \\
\hline Wolters Kluwer & 5 & 5 & 5 & 0 & 2 & 6 & 4 & 2 \\
\hline Total Score & 136 & 160 & 187 & & 96 & 122 & 145 & \\
\hline $\begin{array}{l}\text { Average } \\
\text { Score* }\end{array}$ & 5,67 & 6,67 & 7,48 & & 4,00 & 5,08 & 5,80 & \\
\hline Companies with & decred & ase in $s$ & score & 1 & & & & 3 \\
\hline $\begin{array}{l}\text { Companies with } \\
\text { score }\end{array}$ & no che & ange in & & 3 & & & & 5 \\
\hline Companies with & increa & ise in $\mathrm{sc}$ & core & 18 & & & & 16 \\
\hline
\end{tabular}

* Average score $=$ Total score $/$ total number of companies with published reports

material risks, by 2018 the number had increased to 16 companies (64\% of the sample).

Turning to Table 2, we see that the attention to climate scores of 16 companies increased (64\% of the sample) between 2016 and 2018, of 5 companies remained unchanged, and of 3 companies decreased. Regarding climate action scores, those of 18 companies $(72 \%$ of the sample) increased. Of these 18 companies, the scores of three companies - ABN AMRO, IMCD and Vopak increased appreciably. Furthermore, the climate action scores of three companies remained unchanged, while there was a decrease in the score of one company. Overall, Akzo Nobel is the only company whose attention and action scores both decreased between 2016 and 2018 . We used companies' annual climate attention and action scores to plot the companies on two-dimensional graphs. Figure 1 shows the attention-action graph for the year 2016. The midpoints on the graph's $\mathrm{x}$ and $\mathrm{y}$ axis were used to divide the graph into four quadrants. Looking at the graph, 10 companies in the sample (i.e., 42\%) appear in the first quadrant reflecting low climate attention and low climate action. In addition, 7 companies in the sample (i.e., 29\%) are in the third quadrant reflecting high climate 
Figure 1. Year 2016 attention-action mapping.

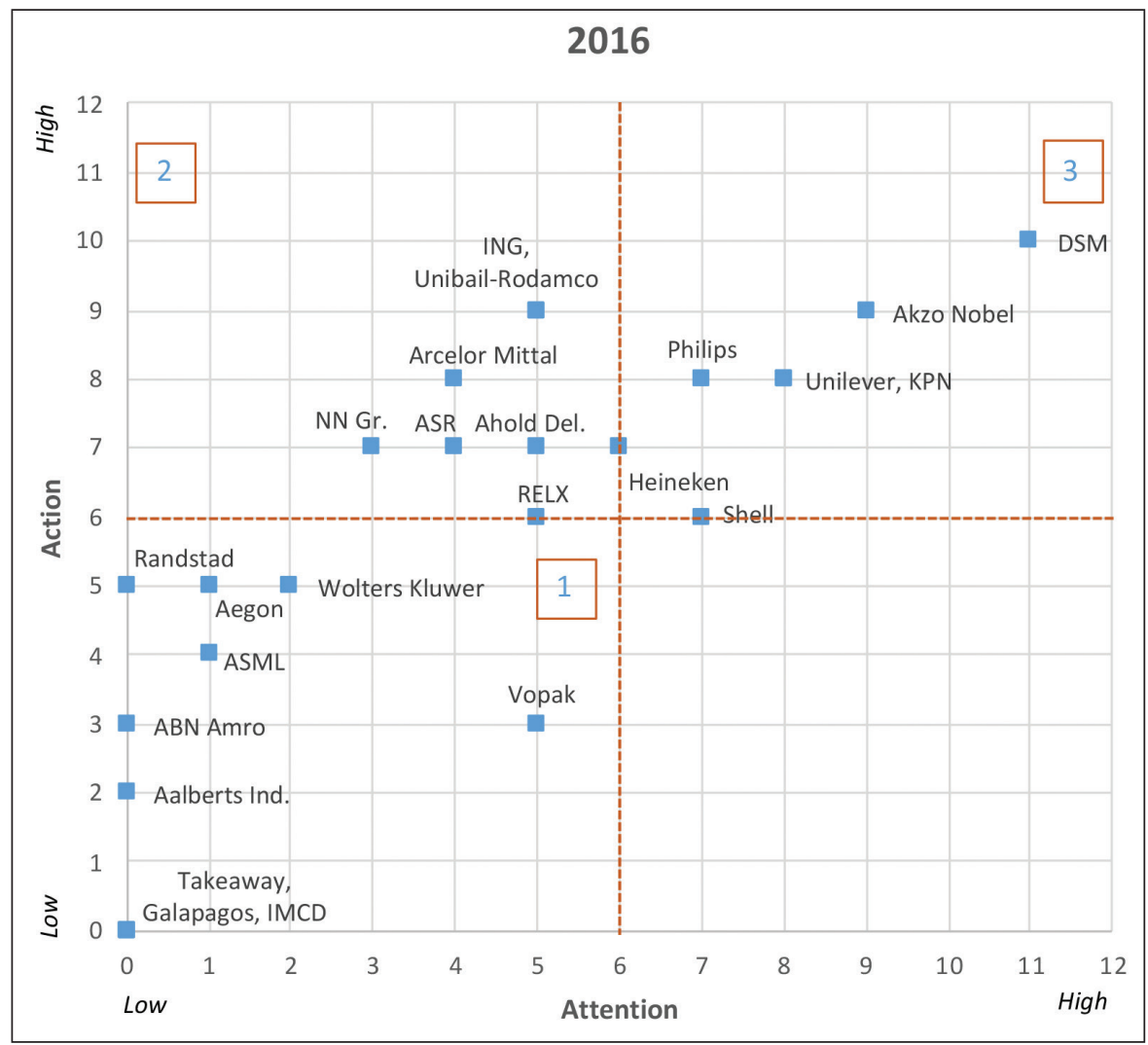

Figure 2. Year 2018 attention-action mapping.

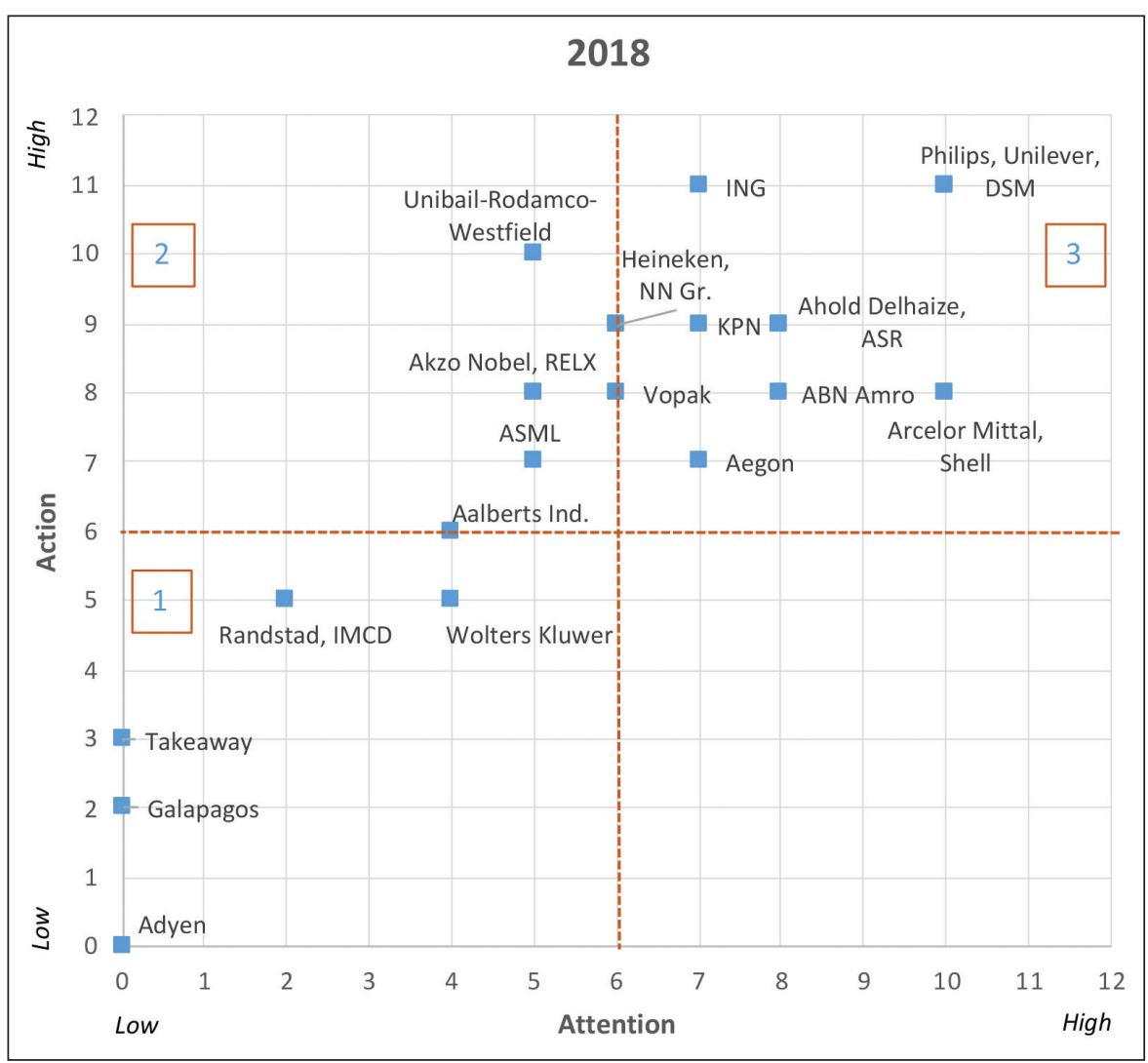


attention as well as high climate action. In line with the literature, thus, our mapping indicates considerable correspondence between attention and action ( $\mathrm{Li}$ et al. 2013; Shepherd et al. 2017), suggesting greater climate attention to be an antecedent of climate action. Notably, though, 7 companies in the sample (i.e., 29\%) are in the second quadrant, having scored relatively low on climate attention but high on climate action. This suggests that some companies may not be communicating or reporting their attention to climate in enough detail (the attention scores in this quadrant were in the lower half of the 12-point range) even though they are taking climate actions.

Figure 2 shows the attention-action graph for the year 2018. Relative to the year 2016, the number of companies in the first quadrant decreased to 6 (i.e., 24\%) in 2018. The decrease is due to either an upward or a rightward move on the graph by companies. The change implies an increase in climate attention and climate action over the 2016-2018 period by AEX companies as a set. Accordingly, the number of companies in the third quadrant, which reflects high climate attention as well as high climate action, is 14 (i.e., $56 \%$ ) in 2018. Furthermore, 5 companies in the sample (i.e., $20 \%$ ) are in the second quadrant, having scored relatively low on climate attention but high on climate action. Interestingly, the three companies that have the lowest climate attention and climate action scores are companies that have been the shortest on the AEX listing. This suggests that the public scrutiny that an AEX listing brings may put pressure on companies and incentivize them to engage more with the issue of climate (see also Ioannou and Serafeim 2015; Flammer 2013). Overall, then, we find cross-sectional variation across firms in their climate attention and climate action scores. We also find some increase in both climate attention and climate action scores over time.

\section{Discussion and conclusion}

Watershed events such as the 2015 Paris Agreement and the E.U. non-financial reporting directive have added a sense of urgency to the calls for voluntary and mandatory disclosure of companies' engagement with climate issues connected to their business. In this context, the present study examines the corporate reports of publicly listed companies in the Netherlands to document their attention to climate issues from 2016 to 2018 and the climate actions they took. The attention-action mapping exercise we present is new to the literature on climate-related reporting. Our analysis shows that the companies in our sample differ in terms of their climate attention and climate actions, and that more attention is related generally to more action. The analysis also reveals considerable differences in attention and action across firms. Considering that all firms in our sample are large in terms of market capitalization, are traded frequently, and are subject to similar public scrutiny and stakeholder pressures, the differences in their attention and actions presumably reflect differences in industry, firm and intra-firm factors.
Interestingly, referring to the difference between climate attention and climate action scores that underlie the mapping shown in Figure 2, Arcelor Mittal and Shell stand out as companies that are among the highest scoring on the climate attention aspect. They however trail others in terms of climate action. A plausible explanation for this may be that the challenge for both companies to take action is outsized given the nature of their business. More climate action is probably still to follow for both companies. It may also be that the two may not be communicating their climate actions fully in their corporate reports. Furthermore, Figure 2 points to Aalberts Ind., Akzo Nobel, ASML, RELX group, and Unibail-Rodamco-Westfield as companies whose climate action scores are higher than their climate attention scores. Inspection of data indicates that, except for Akzo Nobel, this can be ascribed to climate not having been included explicitly in these companies' policy and strategy making (for example, climate discussions may not have featured on the boards' agendas). A potential hazard of such an approach is that climate actions may have an impromptu character (Maas et al. 2016). The noted companies would therefore be well advised to give attention to climate in their policy and strategy formulation, so that, a coherent set of climate actions follows. Maas et al. (2016) suggest, for example, an integrative approach that weaves sustainability issues into the firm's vision and strategy.

In addition, AEX firms' climate attention and climate action scores mostly increased between 2016 and 2018 . This is consistent with the more intense pressure on firms to engage with climate issues and to share publicly the climate actions they have taken. A look at individual indicators of climate attention in 2018 reveals that in terms of external communication, climate issues were explicitly mentioned in the CEO letters-to-shareholders of only 11 AEX firms (i.e., 44\%). Many CEOs, thus, still do not give much attention to climate when communicating with shareholders and potential investors. However, by 2018, 21 AEX firms (i.e., 88\%) had paid some attention to climate change in the context of strategy formulation. In all but one case, companies also reported steps to reduce carbon emissions, plausibly reflecting an attention-action dynamic. In a similar vein, attention to climate as a material risk was always associated with goals (quantitative or qualitative) and steps to combat climate change. Surprisingly, climate was included on the agenda of non-executive directors (NEDs) on supervisory boards of only 9 AEX firms (i.e., 36\%). This suggests that CEOs and executive directors seem to pay more attention to climate than NEDs, even though the latter supposedly have a major role to play in this regard.

On the whole, our investigation indicates that attention to climate and climate-related actions are on the rise among AEX companies. Moreover, inasmuch as greater climate action follows greater climate attention, the increase in attention in the last years can be expected to lead to more action in the future. This said, one message to come from this study for corporate leaders is that firms 
can do much more in terms of engaging with climate than they seem to do currently. For example, we did not find across the board evidence for a comprehensive approach to climate-related risk management. In a context in which the Dutch Central Bank (Preesman 2019) has started conducting climate stress tests on Dutch financial institutions, companies would do good to include climate in their risk management efforts. Otherwise, companies run the risk of being left with stranded assets, just like Uniper MPP3 (formerly EON) was when it had to close its innovative coal powered electricity plant. Moreover, unprepared companies may face physical risks (for example, because of rising sea levels or changes in weather patterns), legal risks due to lawsuits, market risks on account of shift in customer preferences, and cost base risks because of extra expenditures and investments to cope with the effects of climate change. With regard to climate risks specifically, but also more generally, this study indicates somewhat limited involvement of firms' supervisory boards with climate issues. Climate was seemingly on the NEDs' agenda only in roughly one-third of the companies.

An additional message to come from our study therefore is that companies should seek a greater engagement of NEDs with climate issues. The involvement of NEDs is likely to enhance attention to climate, because strategy discussions become richer with the availability of a more diverse range of perspectives and suggestions (e.g., Bos- boom et al. 2019; Sidhu et al. 2020). This, in turn, is likely to have a positive impact on climate actions. It is worth underlining in this context that NEDs have a fiduciary obligation towards shareholders and stakeholders to monitor the executive function's efforts to address climate issues and to communicate them externally. Indeed, NEDs may, whenever necessary, consider taking the lead in asking the executive management about attention to climate and how a firm's mission and strategy take the climate into account. NEDs can act as sparring partners of executives confronted with climate dilemmas and offer their advice and counsel.

As any other piece of research, our descriptive account of AEX firms also has limitations. One limitation of our study is that it focused only on large firms. As a result, we do not know how medium-sized and smaller firms' attention to climate and climate actions compare to those of larger firms.

Future work could thus seek to expand our study by examining a broader sample of firms. In addition, the scope of this study did not allow us to examine inter and intra-industry differences in attention and action, and the reasons for these. Future work in this direction would be of much value. Furthermore, our analysis was based on climate information reported in corporate reports. It would be interesting to know in the future how disclosures in corporate reports tally with companies' mandatory climate reporting.

- Drs. J.H.P.M. Stolker is director at the Erasmus Governance Institute, Erasmus University Rotterdam.

- M.Sc. B. Keskin den Doelder is associate researcher at the Impact Centre Erasmus, Erasmus University Rotterdam.

- Prof. dr. J.S. Sidhu is Chair in Strategic Management and Organization, Leeds University Business School, University of Leeds.

- The authors thank Fenna ten Haaf and Max Knigge for their help with data collection.

\section{References}

- BCG [The Boston Consulting Group] Report (2017) Total societal impact: A new lens for strategy. http://on.bcg.com/2z4gKQv

- Bebbington J, Larrinaga C, Moneva JM (2008) Corporate social reporting and reputation risk management. Accounting Auditing and Accountability Journal 21(3): 337-361. https://doi. org/10.1108/09513570810863932

- Beck C, Dumay J, Frost G (2017) In pursuit of a 'single source of truth': from threatened legitimacy to integrated reporting. Journal of Business Ethics 141(1): 191-205. https://doi.org/10.1007/s10551-014-2423-1

- Bosboom B, Heyden ML, Sidhu JS (2019) Boards of directors and strategic renewal: How do human and relational capital matter? In: Tuncdogan A, Lindgreen A, Volberda HW, Van den Bosch FAJ (Eds) Strategic renewal core concepts, antecedents, and micro foundations. Routledge Studies in Innovation, Organizations and Technology. UK: Routledge, 119-139. https://doi.org/10.4324/9780429057861-6

- Cho TS, Hambrick DC (2006) Attention as the mediator between top management team characteristics and strategic change: The case of airline deregulation. Organization Science 17(4): 453-469. https:// doi.org/10.1287/orsc. 1060.0192

- Crane A, Glozer S (2016) Researching corporate social responsibility communication: Themes, opportunities and challenges. Journal of Management Studies 53(7): 1223-1252. https://doi.org/10.1111/ joms. 12196

- Eccles RG, Ioannou I, Serafeim G (2014) The impact of corporate sustainability on organizational processes and performance. Management Science 60(11): 2835-2857. https://doi.org/10.1287/ mnsc.2014.1984

- Eggers JP, Kaplan S (2009) Cognition and renewal: Comparing $\mathrm{CEO}$ and organizational effects on incumbent adaptation to technical change. Organization Science 20(2): 461-477. https://doi. org/10.1287/orsc.1080.0401

- Flammer C (2013) Corporate social responsibility and shareholder reaction: The environmental awareness of investors. Academy of Management Journal 56(3): 758-781. https://doi.org/10.5465/amj.2011.0744 
- Friedman M (1970) The social responsibility of business is to increase its profits. The New York Times Magazine, 13 September: 122-126. http://umich.edu/ thecore/doc/Friedman.pdf

- Ioannou I, Serafeim G (2015) The impact of corporate social responsibility on investment recommendations: Analysts' perceptions and shifting institutional logics. Strategic Management Journal 36(7): 1053-1081. https://doi.org/10.1002/smj.2268

- Kahneman D (1973) Attention and effort. Prentice Hall (Englewood Cliffs, NJ).

- Kamp-Roelands N, Van den Ende H, De Jong M (2019) Klimaatgerelateerde informatie in het jaarverslag. Maandblad voor Accountancy en Bedrijfseconomie 93(11/12): 377-389. https://doi. org/10.5117/mab.93.46442

- Kor YY (2006) Direct and interaction effects of top management team and board compositions on R\&D investment strategy. Strategic Management Journal 27(11): 1081-1099. https://doi.org/10.1002/smj.554

- KPMG, CLP, HKICS (2018) ESG: A view from the top. https:// www.cgiglobal.org/media/bhfltir0/esg_survey_report_en.pdf

- Li Q, Maggitti PG, Smith KG, Tesluk PE, Katila R (2013) Top management attention to innovation: The role of search selection and intensity in new product introductions. Academy of Management Journal 56(3): 893-916. https://doi.org/10.5465/amj.2010.0844

- Maas K, Schaltegger S, Crutzen, N (2016) Advancing the integration of corporate sustainability measurement, management and reporting. Journal of cleaner production 133: 859-862. https://doi. org/10.1016/j.jclepro.2016.06.006

- Nadkarni S, Chen J (2014) Bridging yesterday, today, and tomorrow: CEO temporal focus, environmental dynamism, and rate of new product introduction. Academy of Management Journal 57(6): 1810-1833. https://doi.org/10.5465/amj.2011.0401

- Ocasio W (1997) Towards and attention-based view of the firm. Strategic Management Journal 18(S1): 187-206. https://doi. org/10.1002/(SICI)1097-0266(199707)18:1+\%3C187::AID-SMJ936\%3E3.3.CO;2-B

- Ortiz-de-Mandojana N, Bansal P (2016) The long-term benefits of organizational resilience through sustainable business practic- es. Strategic Management Journal 37(8): 1615-1631. https://doi. org/10.1002/smj.2410

- Plumlee M, Brown D, Hayes RM, Marshall RS (2015) Voluntary environmental disclosure quality and firm value: Further evidence. Journal of Accounting and Public Policy 34(4): 336-361. https://oi. org/10.1016/j.jaccpubpol.2015.04.004

- Porter M, Kramer M (2011) Creating shared value: How to reinvent capitalism - And unleash a wave of innovation and growth. Harvard Business Review 89(1/2): 62-77.

- Preesman L (2019) DNB sees gradual, lasting economic impact from stress test shocks. IPE Magazine, 18 December 2019. https://www. ipe.com/news/dnb-sees-gradual-lasting-economic-impact-fromstress-test-shocks/10042854.article

- Reid E, Toffel M (2009) Responding to public and private politics: corporate disclosure of climate change strategies. Strategic Management Journal 30(11): 1157-1178. https://doi.org/10.1002/smj.796

- Shepherd DA, Mcmullen JS, Ocasio W (2017) Is that an opportunity? An attention model of top managers' opportunity beliefs for strategic action. Strategic Management Journal 38(3): 626-644. https:// doi.org/10.1002/smj.2499

- Sidhu JS, Heyden ML, Volberda HW, Van Den Bosch FAJ (2020) Experience maketh the mind? Top management teams' experiential background and cognitive search for adaptive solutions. Industrial and Corporate Change 29(2): 333-350. https://doi.org/10.1093/icc/ dtz041

- Stubbs W, Rogers P (2013) Lifting the veil on environment-social-governance rating methods. Social Responsibility Journal 39(4): 622-640. https://doi.org/10.1108/SRJ-03-2012-0035

- Weaver GR, Trevino LK, Cochran PL (1999) Integrated and decoupled corporate social performance: Management commitments, external pressures, and corporate ethics practices. Academy of Management Journal 42(5): 539-552. https://doi.org/10.5465/256975

- Westphal JD, Fredrickson JW (2001) Who directs strategic change? Director experience, the selection of new CEOs, and change in corporate strategy. Strategic Management Journal 22(12): 1113-1137. https://doi.org/10.1002/smj.205 